\title{
LEP Gene
}

National Cancer Institute

\section{Source}

National Cancer Institute. LEP Gene. NCI Thesaurus. Code C95047.

This gene plays a role in the modulation of appetite and the regulation of body fat storage. 